\title{
Fractured Perspectives
}

\author{
Gareth Proskourine-Barnett \\ Royal College of Art \\ White Cottage, Harlyn Drive \\ London HA5 2DA, UK \\ garethproskourinebarnett@gmail.com
}

\begin{abstract}
Brutalist Architecture is dead. It is a ghost. Its image haunts us, reminding us of a future that never came to be. But what if Brutalism didn't die? What if we could open up a channel of communication with its ghost? What secrets might it reveal? Google Street View acts as a time machine, allowing us to explore architectural ghosts such as the Birmingham Central Library. As you move through Street View the buildings structure is in a permanent state of flux, constantly dissolving and then reforming. As the buildings form collapses so does the idea that architecture is static or immobile. We are not moving, the buildings are. This lecture explores the implications of these movements on the Birmingham Central Library and how this alters our perception of fact and fiction. As the image mutates information is lost and new meanings are up for grabs. The idea of our virtual and physical worlds being separate entities is becoming indistinct and the question of which space is more real increasingly blurred. As files are compressed and downloaded in cyberspace they lose information, they move from their original context into new spaces, acquiring alternative meanings along the way. This performative lecture weaves together real and imagined histories to investigate the relocation of the Birmingham Central Library to Taiwan in 2018. By adopting the role of the cyber-flaneur I will navigate my way through time and space, exploring the implications of a landscape dematerialised and the potential of moving buildings; the Internet providing a readymade aesthetic to visually articulate the distortion of time and history, describing a world where ruins have become utopias and where archaeology and futurism merge.
\end{abstract}

Hauntology. Brutalist architecture. Media archaeology. Cyber-flaneur. Low resolution. Mutation. Dislocation.

\section{INTRODUCTION}

This is a story about a building. It was a building that was once made of concrete. It was a building once made of cake (Figure 1). It is a building that has now been demolished. There were no explosions, fireworks or light shows, just a slow and brutal deconstruction, an unspectacular spectacle. The site is now a void. It is an in-between space. A space of absence and possibilities.

This is a story about the future. This is also a story about the past. It is the future in the past and the past in the future, a future-future in the past and a past-future in the future. This is a story about movement and mutation. It is about stable and unstable spaces. It is about a haunted landscape and the ghosts of a forgotten idea. Utopia.

\section{THE BIRMINGHAM CENTRAL LIBRARY}

The building is the Birmingham Central Library. It was completed in 1974 and designed by the architect John Madin. It is, or was, considered an impressive example of Brutalist Architecture.

- In 1974, the Three-Day Week was introduced by the Conservative Government as a measure to conserve electricity during the period of industrial action by coal miners.

- Bob Latchford, the Birmingham City centre forward, became Britain's most expensive footballer in a £350,000 move to Everton.

- Architect John Poulson was jailed for five years for corruption.

- The second General Election of the year resulted in a narrow victory for Harold Wilson, giving Labour a majority of three seats.

- The first UK McDonalds opened in Woolwich, Southeast London. 
- In Birmingham, bombs planted by a Provisional IRA member exploded, killing 21 people and injuring many others. The Birmingham Six were charged with the pub bombings. They would serve nearly 17 years behind bars in one of the worst miscarriages of justice seen in Britain. They were described as having been in the wrong place at the wrong time.

Madin's library was part of an historic period, when Birmingham was undergoing a previous age of renewal. The library embraced an urban ideology of a brave new world, one dominated by the car. At the time, it resonated with the city's legacy of progress, innovation and construction Birmingham's motto is Forward. The Central Library was a centre point for this age of renewal forming part of a post-war utopian redesign of the civic centre that was to remain only semi completed due to imposed budget cuts.

The library and its surrounding structures are now being demolished in preparation for a new commercial development, expected to transform the city centre towards a pedestrian focused public realm. I think this is planner talk for building more retail spaces. The library was not an old building; it was just 42 years old. It was not in a state of disrepair and yet it has been demolished. What does this tell us? Perhaps it tells us that Brutalist Architecture is dead.

How did it die? Was it murdered with an EX1200 hydraulic high reach excavator punching its way through the buildings core. Spraying the concrete with fine jets of water whilst slowly tearing the building apart with its giant mechanical pincer. The skeletal frame stripped of dignity. In amongst the ruins new structures and configurations emerge. If only for a brief moment. The building splits down the middle, opening up to create a passageway between 2 squares - Chamberlain and Centenary. The Museum and Art Gallery sees the Symphony Hall. The demolition hinting at potential alternative adaptations of the site. The Architecture firm BPN submitted an entry to the Civic Society Architecture Competition to imagine new uses for the city landmark. The plan was rejected. Temporarily a fiction became a reality. BPN's reimagining providing a prophetic vision of the buildings future deconstruction. To quote Boris Groys:

Fiction becomes reality when it enters realitywhen the psychological conflicts described by art lead to revolutionary action. Before this revolutionary moment, "realist fiction" remains a fiction (Groys 2016).

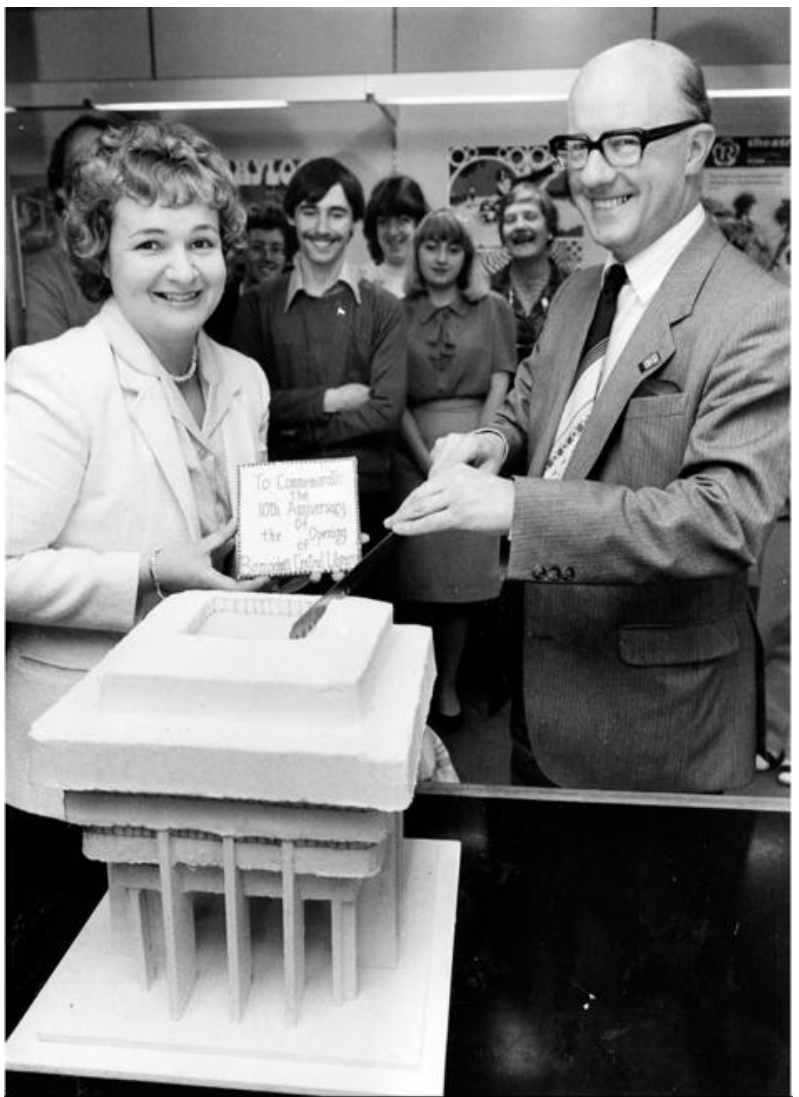

Figure 1: The $10^{\text {th }}$ Anniversary of the opening of the Birmingham Central Library.

\section{NEW TERRITORIES}

But what if Brutalism didn't die? What if it was able to move? What if it was able to find new territories to occupy? What if it was no longer limited by or confined to its raw materials? Where might we search for traces of its existence? What secrets might it reveal?

The walk is always the starting point. It is the route to understanding. The walk is an attempt to time travel, it is an attempt to unlock the landscape. The walk is the means from which to interrogate the ideology imbued in the fabric of the architecture, exploring the transitory and contradictory nature of our cities, of our world, of our time.

I enter into the street, I walk, I drift, I occupy space, physical and virtual, I become the cyber-flaneur. The cyber-psychogeographer. Cyberspace provides a territory in which to encounter and document the ghosts that haunt our landscape. The Internet providing a ready-made aesthetic to visually articulate the distortion of time and history already taking place in our physical world, it describes a world where ruins have become utopias and where archaeology and futurism merge. 
Unexpected narratives might reveal themselves but the landscape will never expose itself completely. The Incas believed that we walked into the past backwards. They also believed that the past, present and future all occupied the same space at the same time. They believed in multiple times, Pasts, presents and futures all cohabiting and coexisting simultaneously.

I walk slowly. Speed is important. Walking is movement. Walking is motion. Forward Backwards - Left - Right. We move and the world moves around us. All that appears solid reveals itself to be anything but - stability is nothing more than a myth. Fragments appear and then disappear. Temporal disruptions to history.

\subsection{Another space}

If you don't want a man unhappy politically, don't give him two sides to a question to worry him; give him one. Better yet, give him none. Let him forget there is such a thing as war. If the government is inefficient, top-heavy, and taxmad, better it be all those than that people worry over it. Peace, Montag. Give the people contests they win by remembering the words to more popular songs or the names of state capitals or how much corn lowa grew last year. Cram them full of non-combustible data, chock them so damned full of 'facts' they feel stuffed, but absolutely 'brilliant' with information. Then they'll feel they're thinking, they'll get a sense of motion without moving. And they'll be happy, because facts of that sort don't change (Fahrenheit 451 1966).

Prince Charles described Birmingham's Central Library as, "a place where books are incinerated, not kept". Perhaps he had recently watched the 1966 British science fiction film Fahrenheit 451.

The modernist architecture of the Alton Housing Estate in Roehampton, South London, designed by the London County Council Architects (LCC), provides a backdrop for the oppressive future society in Fahrenheit 451. The film takes place in a dystopian future where the government fears an independent-thinking public. The Alton Estate is a combination of subtle mixed-density Scandinavian inspired housing in Alton East and the slab-block high-rises in Alton West that referenced Le Corbusier's Unite d'Habitation in Marseille. Alton West in particular is an early example of what British architectural critic Reyner Banham would term New Brutalism.

Brutalist architecture has appeared in film before, in A Clockwork Orange Stanley Kubrick used the Thamesmead estate as well as the Lecture Centre at Brunel University to provide the dystopian backdrop to Anthony Burgess' novel about free will and control and in Get Carter the Gateshead multi- story car park famously provided the setting for Michael Caine's character Jack Carter to throw Cliff Brumby to his death and. Cinema allows Brutalism to live on in an alternative or parallel universe. By committing the building to film, it enters another space - a space where it is free to acquire a new history. The seven-storey Trinity Square car park in Gateshead was designed by Owen Luder. Only it wasn't really designed by Owen Luder or it might of been. Rodney Gordon is often credited with the design but according to Luder his "involvement... was limited to leading the initial design group working up Luder's sketches"; according to Luder he sketched the initial concept for Trinity Square on the train journey back to London after his initial site visit. The design was closely modelled on the architect's Tricorn Centre, a concrete-bodied shopping centre completed in Portsmouth in 1966. Luder said that "[t]he scheme that he sketched on the train basically was the same as the Portsmouth scheme".

Construction of the concrete frame began in 1962, with the centre opening in 1969. The heavily textured surface of the concrete was imprinted with the timber of its shutter board mould. Original plans included a rooftop nightclub that was to occupy the glazed box that topped the car park, but a lease was never agreed. Two external wells situated either side of the car park took the staircase and lifts outside the main floor plan of the building, freeing up space to allow maximum car-parking capacity. These access towers were a feature replicated in several of Luder's Brutalist designs, including the Grade II listed Eros House in Catford, southeast London.

Earmarked for redevelopment by Gateshead Council in the early 2000s, a campaign to save the complex was unsuccessful and Trinity Square closed its doors for the final time in 2008. Demolition was completed in 2010 and a new development opened on the site in 2013. Lumps of the reinforced concrete structure were tinned and sold off at a cost of $£ 5$ as keepsakes by the council that demolished it.

\section{CONCRETE}

Concrete is a composite material composed of coarse aggregate bonded together with a fluid cement, which hardens over time. In hydraulic cement concretes when the aggregate is mixed together with the dry cement and water, they form a fluid mass that is easily moulded into shape. The cement reacts chemically with the water and other ingredients to form a hard matrix, which binds all of the elements together into a durable stone-like material that has many uses. 
It was around the intersection of the A4400 and the A38 that I came across this abandoned fragment, this ghost. A portable security gatehouse had been erected on the slip road into the service and goods entrance. It was there that this piece of debris revealed itself. The demolition process had only just begun on Birmingham's Central Library. The contractors had not long moved in and there was still no real visible damage to the exterior.

This lump of concrete, this composite material. How do we understand it? How do we make sense of it? This fragment. It is heavy and rough to touch. It has scars. The object is surprisingly colourful. But, It was never meant to be concrete. Madin's original plan was to build the Library from Portland Stone. A completely different material. This material, concrete, was a mistake. It was never intended. It is the result of budget cuts. As a result Portland Stone haunts Madin's Library, it is in its absence that it is present. Imbedded within the coarse aggregate and cement is the potential of this other material. It has potentiality.

\subsection{Show me the real}

It is only as I navigate my way through the digital incarnations of Brutalism that I begin to comprehend the unstable nature their existence. They are not static, stable or permanent but instead they are constantly changing. The only thing that is permanent is a constant state of flux. These digital images of Brutalism highlight the importance of movement within our constructed environment - in fact movement lies at the heart of architecture. In order to interact with a building we need to walk through it. It is only by traveling though the site that we experience the site. They are anything but concrete.

We use the cursor to progress in a given direction or to shift our point of perspective, as we do the building's structure collapses and then reforms. For a split second it is a void. It fragments and as the image mutates information is lost and new meanings begin to take shape. Perhaps a new history is possible. The buildings seams are pulled apart, its edges dissolve and it moves. It is a moving building - just like the architecture collective Archigram proposed back in 1964.

Archigram's walking building was a giant reptilian structure that would freely roam the world, moving to wherever it was needed whilst being able to connect to other walking buildings when required in order to form larger cities. Perhaps that is what is happening. Perhaps Birmingham's Central Library could grow some legs, hoist itself up to standing and walk to another city where it might be a little more appreciated. Stranger things have happened.

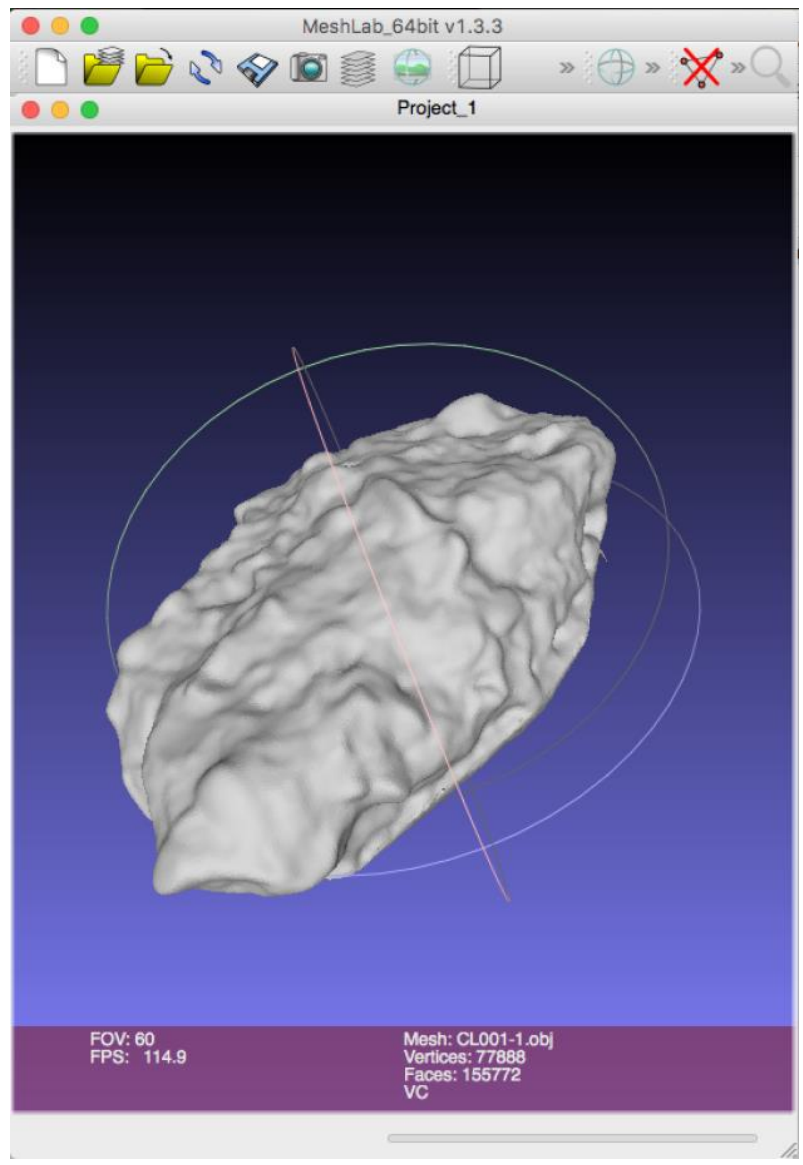

Figure 2: 3D Scan of Concrete debris from Birmingham Central Library

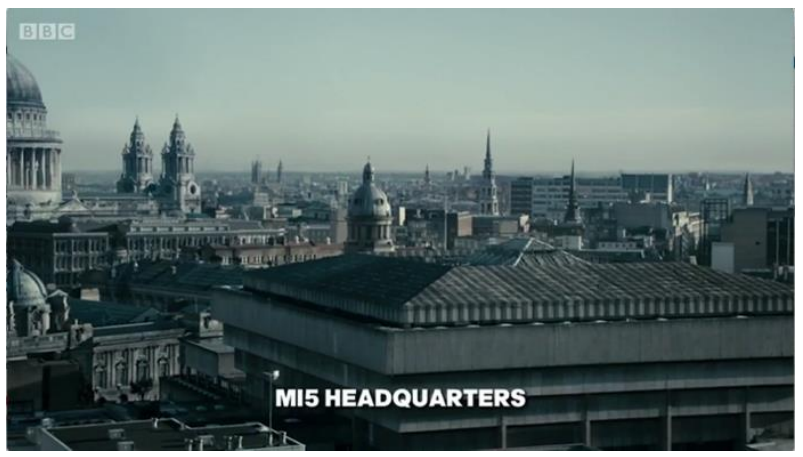

Figure 3: Still from The Game

The Central Library re-appears during the BBC mini series The Game, a cold-war espionage thriller involving an internal mole within MI5 and a Soviet plan to overthrow the UK government. It was well received enough but what was particularly interesting about the show was its use of Brutalist architecture.

Madin's Library was uprooted and transplanted into the heart of London where it served as the MI5 headquarters. The Game is about the Cold War but this building is not the typical embodiment of dystopia, the libraries exterior becomes a protective fortress. Internally, the beautifully ribbed concrete walls provide spaces for secret interactions that are 
not sinister or brooding with violence. These are spaces of romance. Spaces in which to fall in love.

Where is the real? Somebody show me the real? Doubting documentary representation is of course nothing new. As Hito Steyerl says:

The closer to reality we get, the less intelligible it becomes. Let us call this 'the uncertainty principle of modern documentarism' (Steyerl 2011).

Brutalism has moved into and beyond the screen, as it becomes digitised it becomes unstable, its permanence becomes vulnerable and it is susceptible to piracy. As images move through digital networks they lose information and they mutate. Within these mutations there is the potential to create new meanings. The more an image is copied the more distorted it becomes and as such the further it moves from its original position. It moves into a space free from past associations. It is free to acquire new meanings.

Mecanoo architects have recently won a competition to design the new Tainan Public Library in Taiwan. Their winning design "represents the meeting of cultures, generations and histories", says the architects. It will feature an inverted stepped facade that houses reading rooms, special collections, study spaces, a children's area, café, conference hall, a 200-seat auditorium, and public courtyards. The architects have said:

Tainan is a city born from a history of diverse cultures, peoples and traditions. The urban fabric holds memories from the 17th century European maritime trading, the Qing Dynasty Ruling, and the Japanese settlement of the early 1900 s. On top of its rich history, modern Tainan is developing as a central city in the knowledgebased economy. The Public Library is about Tainan's evolving relationship with its past and the direction towards its future (Fulcher 2016).

Mecanoo have built other libraries, famously Europe's largest public library in Birmingham with a sunken amphitheatre, rooftop gardens and a shimmering facade clad with interlocking metal rings. Mecanoo's library effectively replaced John Madin's Central Library. I can't help but notice a striking similarity between the Tainan proposal and Madin's now demolished inverted concrete ziggurat.

To quote Boris Groys again:

Fiction becomes reality when it enters realitywhen the psychological conflicts described by art lead to revolutionary action. Before this revolutionary moment, "realist fiction" remains a fiction (Groys 2016).

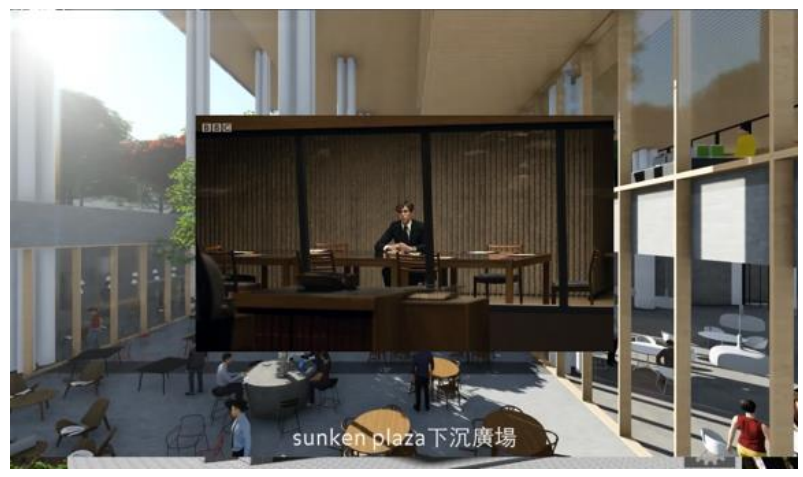

Figure 4: Still from performed lecture.

\subsection{Closing extract}

The geese fly south in winter.

Ahh yes but the gander is erm no the gander I mean the gander tends to

What the gander

And their eggs are most plentiful when

Please, stop, this is painful. I heard what happened, oh my love.

I'm fine. Jo and that Jim chap engaged. I'm ashamed to say I hid.

I'd of been furious if you hadn't. I want to have the conversation.

\section{Oh Sarah}

No not that one. The Marconi one. Someone died tonight, yards away from you. All I'm saying is with someone like your skills you could walk straight into somewhere like Marconi.

Is this really about my safety. You're destined for great things and a husband who tinkers with wires and microphones is hardly

Is that why you think I want you to get a different job? To make you more suitable for me?

\section{People talk Sarah}

But they don't understand us. Not in this world.

(They Kiss)

Come on...

(The Game, 2014).

\section{REFERENCES}

Fahrenheit 451 (1966) [film]. Directed by François Truffaut. Universal Pictures, UK.

Fulcher, M. (2016) Mecanoo Wins £30m Taiwan library contest. 
https://www.architectsjournal.co.uk/news/mecanoowins-30m-tainan-library-contest/10003181.article (retrieved19 March 2018).

Groys, B. (2016) Towards The New Realism. http://www.e-flux.com/journal/77/77109/towardsthe-new-realism/ (19/03/18)
Steyerl, H. (2011) Documentary Uncertainty. http://re-visiones.net/anteriores/spip.php\%3Farticle 37.html (retrieved 19 March 2018).

The Game (2014) [TV mini-series]. Directed by Toby Whitehouse. BBC, UK. 